\title{
Decentralizacija organa unutarnjih poslova u SR Hrvatskoj
}

\author{
CHRISTIAN AXBOE NIELSEN \\ Aarhus University
}

\begin{abstract}
Sažetak
Kako su se organi unutarnjih poslova u Socijalističkoj Republici Hrvatskoj i u socijalističkoj Jugoslaviji razvijali, čime su se bavili, do kakvih je promjena došlo i zbog čega? Tijekom otprilike prva dva desetljeća socijalističke Jugoslavije pitanja koja su se odnosila na policiju i državnu sigurnost - ili službenim nazivom na organe unutarnjih poslova - bila su poput većine ostalih pitanja u zemlji vrlo centralizirana. Međutim, postoje indicije da 1966. možda nije bila toliko značajna prekretnica kako se popularno misli te da su neke važne promjene bile ubrzane, a ne pokrenute nakon smjenjivanja Aleksandra Rankovića. Ovaj članak prvenstveno se temelji na izvorima iz 13. maja, službenog časopisa Saveznog sekretarijata za unutrašnje poslove (SSUP). Pažljivo čitanje tog časopisa otkriva članke koji se bave pravnim, konceptualnim, tehničkim i praktičnim pitanjima policije. Časopis je stoga dobro mjesto za prikupljanje informacija radi boljeg razumijevanja organa unutarnjih poslova u Jugoslaviji. Ovaj članak razmatra i analizira početak decentralizacije organa unutarnjih poslova u Hrvatskoj, prije svega u području organa javne sigurnosti.
\end{abstract}

Ključne riječi: Ministarstvo unutarnjih poslova, decentralizacija, općine, policija, javna sigurnost

\section{Uvod}

Socijalistička Jugoslavija postojala je kao komunistička partijska država od 1945. do raspada 1991., a za to su vrijeme sigurnosne snage - milicija, državna sigurnost, teritorijalna obrana i vojska - funkcionirale kao stupovi režima. ${ }^{1}$ Usprkos tome, znanstvena literatura je samo u veoma ograničenoj mjeri obradila svakodnevno funkcioniranje tih snaga, odnosno službi. Kao i u drugim bivšim socijalističkim zemljama,

${ }^{1}$ Ovaj je rad financirala Hrvatska zaklada za znanost projektom HRZZ IP-01-2018-5394. 
većina postojeće literature o represivnom aparatu fokusirana je na brutalnu represiju i zločine koje su jugoslavenske sigurnosne snage počinile na kraju i odmah poslije kraja Drugog svjetskog rata, odnosno tijekom staljinističke faze Jugoslavije do 1953. ${ }^{2}$ Povjesničari su se s razlogom posvetili istraživanju poratnih masakra poput Bleiburga, poratnih "čišćenja” i represije na Golom Otoku poslije raskola Tita i Staljina, a u stalnom je porastu broj znanstvenih publikacija o Službi državne sigurnosti (SDS). ${ }^{3}$ Te teme, naravno, zaslužuju mnogo pažnje, ali i dalje znamo relativno malo o svakodnevnom policijskom djelovanju u Jugoslaviji nakon staljinističkog razdoblja. S obzirom na to da je riječ o razdoblju koje je trajalo gotovo četrdeset godina, krajnje je vrijeme da povjesničari razmotre pitanje: kako su se organi unutarnjih poslova razvijali, čime su se bavili, do kakvih je promjena došlo i zbog čega? A s obzirom na to da decentralizacija podrazumijeva prenošenje određenih nadležnosti na općine, treba se zapitati i kako su se općinski organi unutarnjih poslova snašli u kontekstu decentralizacije, odnosno do kojih izazova i problema je došlo. Vremenski okvir za ovaj članak počinje oko 1966. godine, koja je zbog Četvrtog (Brionskog) plenuma SKJ poznati prijelomni trenutak u jugoslavenskoj povijesti, a pogotovo $u$ povijesti organa unutarnjih poslova. Naglasak će u ovom članku biti na javnoj sigurnosti, koja je činila veći dio organa unutarnjih poslova u socijalističkoj Hrvatskoj i Jugoslaviji, ali koju su znanstvenici dosad uglavnom zapostavljali.

Prije nego nastavimo, treba nešto reći o stanju arhivske građe. Premda je situacija, barem što se tiče Hrvatskog državnog arhiva, mnogo bolja otkad je fond SDS-a Republičkog sekretarijata (ministarstva) za unutarnje poslove (RSUP) SRH postao dostupan, stanje za povjesničare koje zanimaju milicija i javna sigurnost i dalje je daleko od poželjnog. Naime, količina dostupne dokumentacije koja se direktno odnosi na te teme je zanemariva. Paradoksalno je da je neto zbroj dostupnih izvora Službe javne sigurnosti, čiji je rad bio znatno manje osjetljive prirode, mnogo manji od izvora SDS-a. Dokumentacija se mora tražiti u srodnim fondovima u kojima državni i partijski organi razgovaraju o tim pitanjima. Nepotrebno je napomenuti da ta vrsta istraživanja traje mnogo duže.

Uzimajući u obzir stanje arhiva, ovaj će se članak prvenstveno temeljiti na drugoj vrsti izvora, naime na 13. maju, službenom časopisu Saveznog sekretarijata za unutrašnje poslove (SSUP). ${ }^{4}$ Taj je časopis bio publikacija u kojoj su vodstvo

2 Zapravo je prilično teško pronaći solidnu znanstvenu literaturu o miliciji/policiji u socijalističkim državama. Dva primjera su Hagenloh (2009) i Shearer (2009).

${ }^{3}$ Od novije relevantne znanstvene literature o sigurnosnom sustavu u Jugoslaviji vidi Previšić (2019); Cvetković (2011; 2013); Dornik Šubelj (1999; 2013); Nikolić (2013); Radelić (2019).

4 Od 1948. do kraja 1963. SSUP je objavljivao časopis Narodna milicija, koji je u siječnju 1964. preimenovan u 13. maj. Treba dodati da se časopis Narodna milicija, pogotovo u prvim godinama, mnogo manje bavio "teškim" stručnim pitanjima, a više je imao karakter zabavnog ili sindikalnog časopisa usmjeren na obične policajce, odnosno milicionere. 
SSUP-a i ostali zaposlenici mogli artikulirati i raspravljati o širokom nizu pitanja važnih za rad organa unutarnjih poslova, a prije svega organa javne sigurnosti. Pažljivo čitanje tog časopisa otkriva vrlo detaljne članke koji se bave pravnim, konceptualnim, tehničkim i praktičnim pitanjima policije. Časopis je stoga dobro mjesto za prikupljanje informacija radi boljeg razumijevanja organa unutarnjih poslova $u$ Jugoslaviji. Određeni broj članaka usredotočen je na organe unutarnjih poslova u Hrvatskoj. Svakako treba imati na umu da su u tom časopisu objavljeni samo članci kompatibilni sa službenom (partijskom) linijom te se prema tome mora održati kritički pogled prema njima. Ali, istodobno, autori u časopisu pokazuju relativno dobru sposobnost da na kritički način postavljaju relevantna pitanja i pokazuju želju za iskrenom raspravom o problemima koji se pojavljuju tijekom provođenja relevantnog zakonodavstva, uputa i regulacija. Analitička vrijednost dobivena kritičkim čitanjem tih članaka stoga je velika. Pored toga treba napomenuti da je i ostalih pet konstitutivnih republika Jugoslavije imalo vlastiti časopis o unutarnjim poslovima. ${ }^{5}$ U SR Hrvatskoj je državni (republički) sekretarijat za unutrašnje poslove počevši od studenoga 1953. izdavao i Priručnik za stručno obrazovanje službenika unutrašnjih poslova. Dok je savezni časopis stavio "težište na obradu općih teoretskih pitanja naše službe, pravno teoretskih pitanja i na načelna stanovišta prema pojedinim zadacima[,] Priručnik postavlja težište na obradu praktičnih pitanja i zadataka pojedine službe u resoru. Obje publikacije se dakle međusobno dopunjuju" (Uredništvo, 1953: 2).

\section{O decentralizaciji u socijalističkoj Jugoslaviji}

Tijekom otprilike prva dva desetljeća socijalističke Jugoslavije, pitanja koja su se odnosila na policiju i državnu sigurnost - ili službenim nazivom na organe unutarnjih poslova - bila su poput većine ostalih pitanja u zemlji vrlo centralizirana. Posebno nakon smjene 1966. godine Aleksandra Rankovića, koji je bio ključna osoba u uspostavljanju jugoslavenske milicije i službe državne sigurnosti, pokrenut je proces decentralizacije koji je kulminirao ustavom iz 1974. Rasvjetljavanjem restrukturiranja i određenih reformi u RSUP-u te njihovih posljedica za rad milicije i za njezinu suradnju s drugim vladinim institucijama i građanima ovaj članak želi dati skroman doprinos povijesti organa unutarnjih poslova u Hrvatskoj i Jugoslaviji. Pored ostalog, mislim da se može reći da, barem što se tiče javne sigurnosti i rada

5 Među tim su časopisima bili: Priručnik za stručno obrazovanje službenika unutrašnjih poslova (SR Hrvatska), Strokovni list ljudske milice i Varnost (SR Slovenija), Bezbednost (SR Makedonija), Bezbednost (SR Srbija). Uz to treba dodati da je Autonomna pokrajina Vojvodina imala Bilten javne bezbednosti AP Vojvodine i časopis Naša praksa. Vidljivo je iz bibliografije Priručnika da su u republičkom sekretarijatu pratili i strane publikacije o policiji, npr. časopise Kriminalistik iz Zapadne Njemačke i The Police Journal iz Velike Britanije. 
milicije, postoje indicije da 1966. možda nije bila toliko značajna prekretnica kako se popularno misli te da su neke važne promjene bile ubrzane, a ne pokrenute nakon uklanjanja Rankovića.

Reći da su sigurnosne snage - milicija, državna sigurnost, teritorijalna obrana i vojska - funkcionirale kao stupovi partijske države nikako ne znači da je ta država bila monolit. Opće je prihvaćeno u međunarodnim istraživanjima da je monolitski totalitarizam idealan tip u Weberovom smislu, a da je realnost mnogo složenija (Kotkin, 1995; Fitzpatrick, 2000; Siegelbaum i Sokolov, 2000). Čak u najčvršćoj, staljinističkoj verziji partijske države bilo je više tenzija, oprečnih tendencija i nedosljednosti, a jugoslavensko društvo poslije 1953. ionako nikako nije više bilo staljinističko, nego prilično drugačije, čak i prije pada Rankovića. Stoji, naravno, da je partijska država inzistirala na tome da milicija i državna sigurnost budu čvrsto pod njezinom kontrolom, to jest da budu samo instrument i poslušni izvršitelj partijske volje. A partija je uvijek živjela u strahu od toga da bi organi državne sigurnosti uspjeli pretvoriti partijsku državu u policijsku državu, i u tom kontekstu treba vidjeti događaje iz 1966.

Međutim, do uspostavljanja policijske države nije došlo. Savez komunista Jugoslavije uspio je sačuvati i učvrstiti svoj vodeći položaj i rukovodstvo nad organima unutarnjih poslova. Državna sigurnost je imala osnovnu zadaću zaštite ustavnog poretka, što s obzirom na sadržaj svakog ustava u socijalističkoj Jugoslaviji samo po sebi znači da je državna sigurnost štitila Savez komunista. ${ }^{6}$ Stupanj centralizacije organa unutarnjih poslova je gotovo uvijek, i poslije donošenja ustava 1974. godine, iz očiglednih razloga ostao veći kod organa državne sigurnosti nego kod organa javne sigurnosti (Perković i Gabriš, 1997).

Za razliku od SDS-a, organi javne sigurnosti imali su mnogo veće mogućnosti za stručan razvoj koji je bio prilično neovisan od partijske države. Konkretno to znači da su imali veći subjektivitet (agency) što se tiče djelovanja u okviru svojih nadležnosti. Poslovi javne sigurnosti, koji su navedeni u idućem dijelu ovog članka, bili su vrlo širokog spektra. Uzmemo li na primjer održavanje javnog reda i mira, suzbijanje imovinskih delikata u turističkoj sezoni ili problematiku delikvencije omladine, jasno je da su to stručni predmeti kojima su se organi unutarnjih poslova u velikoj mjeri mogli stručno baviti. To nikako ne znači da Savez komunista nisu zanimali takvi predmeti - a bilo je i brojnih rasprava o takvim pitanjima na svim razinama Saveza.

Međutim, uglavnom je partijski aparat omogućivao profesionalcima u organima unutarnjih poslova da nastavljaju svoj rad. Zapravo djeluje prilično iznenađujuće koliko rijetko se Savez komunista, socijalizam i različiti ideološki pojmovi

${ }^{6}$ Član 313 Ustava SFRJ, Službeni list SFRJ, br. 9/74, 21. veljače 1974. 
spominju u tekstovima u Priručniku za stručno obrazovanje službenika unutrašnjih poslova. Ideološki okvir partijske države svakako postoji, a ima i članaka povodom godišnjica, značajnih Titovih govora, partijskih kongresa itd. koji izričito podsjećaju čitatelja na taj okvir, ali naglasak je u Priručniku i sličnim časopisima na stručnoj analizi i diskusiji unutar organa unutarnjih poslova (Mišković, 1959). Treba i dodati da je svaki broj Priručnika citirao stručne časopise o unutarnjim poslovima i kriminologiji iz zapadnih kapitalističkih zemalja. Dakle organi unutarnjih poslova pratili su suvremeni stručni i tehnološki razvoj svojih kolega u inozemstvu.

Decentralizaciju organa unutarnjih poslova u SR Hrvatskoj, naravno, treba razmatrati u općem kontekstu decentralizacije i diskusije o tome i u socijalističkoj Jugoslaviji. S jedne strane su tu relevantne diskusije o državnoj upravi, na primjer o ulozi društveno-političkih zajednica. Te su se diskusije vodile od uspostavljanja narodnooslobodilačkih odbora, dakle čak i prije formiranja socijalističke Jugoslavije (Koprić, 1987). S druge strane decentralizacija se tiče velikih marksističkih rasprava o odumiranju države. Upravo je u tom smislu Krsto Pasinović, pravni savjetnik Državnog sekretarijata za unutrašnje poslove (DSUP) u Zagrebu 1959. - dakle opet mnogo prije Četvrtog plenuma - pišući o društvenom upravljanju u organima unutarnjih poslova, na samom početku svog članka napisao: "Društvenopolitički sistem Jugoslavije dosljedno se razvija u smislu marksističke postavke o 'odumiranju države', čime se na vrijeme sprečilo da se državni aparat - pod skoro neminovnim tendencijama birokratizma - postepeno pretvori u silu iznad društva, naročito putem srastanja partijske hijerarhije s državnom administracijom" (Pasinović, 1959: 131). ${ }^{7}$ I kao što je zaključio američki znanstvenik Dennison Rusinow, u Jugoslaviji je bilo kontradikcija barem od prvog zakona o lokalnoj (samo)upravi iz 1952. i u svim kasnijim takvim reformama. ${ }^{8} \mathrm{~S}$ jedne strane bilo je "istine decentralizacije i pluralizacije moći", a s druge strane je partija htjela sačuvati "krajnju kontrolu" (Rusinow, 1978: 98). Kao glavne političke aktere te kontradikcije Rusinow je identificirao Edvarda Kardelja i Aleksandra Rankovića. Glede samoupravljanja u jugoslavenskom društvu, i u organima unutarnjih poslova, Rusinow je izrazio skeptičnost i opet ukazao na "dileme" i izazove između decentralizacije i mogućeg gubitka političke kontrole (Rusinow, 2008: 56-59).

7 Treba tu i podsjetiti na to da su Ranković i njihovi najbliži suradnici kasnije bili optuženi za "etatistički birokratizam". Očigledna je tenzija i proturječnost između teze o odumiranju države i sustava državne sigurnosti koji je u suštini postojao kako bi branio državu.

${ }^{8}$ Riječ je o općem zakonu o narodnim odborima (Službeni list, 22/52) koji citira i Pasinović. U Hrvatskoj je donesen i republički zakon o narodnim odborima kotara i općina (Narodne novine, 34 i 35/52). 


\section{Unutarnji poslovi i javna sigurnost u SR Hrvatskoj i Jugoslaviji}

Prije nego što se pristupi analizi članaka u časopisu 13. maj i raspravi o decentralizaciji unutarnjih poslova, dat ćemo kratak pregled organa unutarnjih poslova u socijalističkoj Jugoslaviji. Struktura policije u Jugoslaviji odgovarala je federalističkoj državnoj strukturi, sa SSUP-om na vrhu piramide, a ispod njega s republičkim i pokrajinskim sekretarijatima na slijedećim razinama te na kraju s općinskim i lokalnim organima milicije. Služba javne sigurnosti i Služba državne sigurnosti zajedno su činile organe unutarnjih poslova. Dok je primarni cilj SDS-a (SDB-a) bila zaštita ustavnog poretka države od unutarnjih i vanjskih prijetnji, javna je sigurnost bila vrlo širok pojam. Prema članu 12 Saveznog zakona o unutarnjim poslovima iz 1966. godine, poslovi javne sigurnosti jesu: "zaštita života i lične sigurnosti ljudi; sprečavanje i otkrivanje krivičnih dela; pronalaženje i hvatanje učinilaca krivičnih dela i njihovo predavanje nadležnim organima; održavanje javnog reda i mira; vršenje kriminalističkih veštačenja; bezbednost saobraćaja na javnim putevima i pružanje neophodne pomoći radi otklanjanja posledica u slučaju opšte opasnosti prouzrokovane elementarnim nepogodama i epidemijama, kao i pogranični poslovi”. ${ }^{9}$ Drugim riječima, mnogo je veća vjerojatnost da bi prosječan građanin SR Hrvatske i Jugoslavije imao kontakt s organima javne sigurnosti nego s organima državne sigurnosti.

\section{Decentralizacija organa unutarnjih poslova u SR Hrvatskoj}

Do 1966. sva su pitanja i teme koje su se odnosile na unutarnje poslove bile ne samo centralizirane nego i izolirane od utjecaja "stranaka", dakle od aktera izvan organa unutarnjih poslova. Zapravo je jedan od glavnih razloga za kasnije svrgavanje Rankovića bio razvoj tobožnje "države unutar države", u kojoj posebice SDS nije uvijek bio pod kontrolom stranačko-državnog vodstva. Suprotno tome, u svibnju 1970. savezni ministar unutarnjih poslova Radovan Stijačić izjavio je da "poslovi bezbednosti poslednjih godina sve više postaju predmet razmatranja širih društvenih i samoupravnih institucija, čime su u značajnoj meri prevaziđena shvatanja da su ovi poslovi prvenstveno stvar specijalizovanih službi” (“Izjava saveznog...”, 1970: 3).

Podrijetlo te promjene vidljivo je već ranije u radu povjereništava za unutarnje poslove u narodnooslobodilačkim odborima. "Prema općem zakonu o narodnim odborima iz 1949., unutrašnje poslove vrše narodni odbori preko povjereništava za unutrašnje poslove. Unutrašnji poslovi ulaze u sastav narodnog odbora, a povjerenik je odgovoran izvršnom odboru narodnog odbora i republičkom organu" (Miš-

9 Savezni osnovni zakon o unutarnjim poslovima iz prosinca 1966. objavljen u časopisu 13. maj, god. 19, br. 12, str. 1097-1108. Svi citati iz časopisa ovdje su navedeni prema izvornim tekstovima, koji su uglavnom objavljivani na srpskom jeziku. 
ković, 1959: 126). Saveznim općim zakonom o narodnim odborima i republičkim zakonima o narodnim odborima kotara i općina iz 1952. "osnovani su za pojedine oblasti srodnih djelatnosti narodnih odbora savjeti kojima se "povjerava izvršenje zakona, propisa narodnih odbora i viših državnih organa, kao i vršenje upravnih poslova"' (Pasinović, 1959: 131). Ti savjeti su do neke mjere omogućili sudjelovanje građana u radu organa unutarnjih poslova. Na temelju izračuna Krste Pasinovića za 1958. godinu, "na području NRH u organima unutrašnjih poslova neposredno učestvuje i utiče ne samo na 'rješavanje poslova', nego i na način rada ovih organa 3.811 osoba" (ibid.: 133). Prvenstveno su se osnivale komisije, odnosno savjeti za javni red i mir, za suzbijanje kriminaliteta u privredi, za maloljetne prestupnike, za sigurnost javnog prometa i za protupožarnu prevenciju (ibid.: 133-134). Ti savjeti bavili su se svakakvim pitanjima, od načina života "Cigana i puta njihovog uključivanja u društveni život" u Slavoniji do prostitucije u Rijeci, suzbijanja kartanja u Bjelovaru i revizije lokalnih propisa u Čakovcu. Pasinović je zaključio da se "preventivna funkcija savjeta i njihovih komisija mogla očigledno vidjeti iz dosadašnjeg izlaganja, jer sama činjenica da je neki problem iznesen na sjednicu savjeta prinudila je zainteresirane organe odnosno organizacije da poduzmu određene mjere" (ibid.: 136). Rubrika "Rad savjeta unutrašnjih poslova" kasnije je postala sustavni dio časopisa Priručnik.

U prosincu 1964. VIII kongres Saveza komunista Jugoslavije postavio je nove zadaće za organe unutarnjih poslova i tražio da bolje surađuju s drugim državnim i partijskim organima, a u travnju 1965. Vojin Lukić, savezni sekretar za unutarnje poslove, zagovarao je uvođenje i razvoj samoupravljanja u organima unutarnjih poslova. Priznao je da ima dosta kolega koji misle da takvom razvoju nema mjesta, pogotovo u SDS-u koji se bavi najosjetljivijim poslovima. Ali odbacio je te brige. "Mislim da nema mesta takvoj bojazni i rezervama... u pogledu obima i sadržine samoupravljanja i njegovog uticaja na vršenje funkcije unutrašnjih poslova" (Lukić, 1965: 259-260). Lukić je prihvatio neophodnost unapređenja i racionalizacija službi javne i državne sigurnosti. Priznao je da "su poverljivost i tajnost pojedinih poslova koje obavljaju pojedine službe i pojedini službenici u okviru organa unutrašnjih poslova... ograničavajući faktor" (ibid.). Ali govorio je i o tome da Jugoslavija postaje "postepeno otvorena zemlja" te da se organi unutarnjih poslova tome moraju prilagoditi. Potrebno je bilo "unapređenje" - modernizacija - službe i njezina "racionalizacija". ${ }^{10}$

Premda je samoupravljanje ovdje manje zanimljivo zato što se prije svega odnosilo na prava zaposlenika organa unutrašnjih poslova, vidi se da su prvi koraci prema decentralizaciji učinjeni već prije Četvrtog plenuma. Tako je već 1965. Miroslav

${ }^{10}$ O otvorenosti Jugoslavije vidi Oreč, 1971: 3-13. 
Žarković pisao o “značajnoj ulozi” savjeta za unutarnje poslove u općinskim i sreskim skupštinama (Žarković, 1965: 178). Podsjetio je na donošenje Zakona o narodnim odborima 1952. i Zakona o unutarnjim poslovima 1956. Ideal je bio da "građani preko svojih predstavnika učestvuju u poslovima svoje službe bezbednosti”. Takva takozvana "demokratska kontrola" bila je neophodna u borbi protiv birokratizma ili, kako su to nazivali poslije Četvrtog plenuma, etatističkog birokratizma. S obzirom na to da je Ranković postao simbol te devijacije od partijske linije, iz današnje perspektive djeluje ironično da je Žarković citirao Rankovića, koji je u svom ekspozeu u Saveznoj narodnoj skupštini 26. srpnja 1956. rekao: "Stepen demokratskog razvitka pojedinih organizacija i ustanova u raznim oblastima našeg društvenog $i$ državnog uređenja treba ceniti, između ostalog, i po tome u kojoj meri društvo preko svojih predstavnika neposredno utiče na njihovo funkcionisanje. To je posebno važno za organizaciju unutrašnjih poslova, s obzirom na zadatke, nadležnosti i ovlašćenja koja se daju organima ove grane državne uprave" (Ranković citiran u ibid.).

Vide se i prije Četvrtog plenuma razmišljanja o važnosti općinskih i lokalnih organa upravljanja. Tako Enver Krzić 1965. piše: "U okviru republike ili opštine nisu od manjeg značaja ni poslovi od interesa za republiku i opštinu. ... U skladu sa postavkama Ustava o opštini kao osnovnoj društveno-političkoj zajednici (član 96 Ustava SFRJ)... danas se u opštinskom organu unutrašnjih poslova vrše svi ili skoro svi unutrašnji poslovi” (Krzić, 1965: 1028). Krzić je stavio naglasak na neophodnu suradnju svih organa unutarnjih poslova i na ulogu općinskih organa kao osnovnih organa unutarnjih poslova.

Ali bez obzira na te riječi Krzića i Lalića postoje indicije da je situacija što se tiče lokalnih organa u SR Hrvatskoj bila daleko od poželjne. Vjekoslav Dude je 1966. upozorio na nepostojanje općinskog organa unutrašnjih poslova u Zagrebu, na kritiku suca za prekršaje, na porast raznih vrsta kriminaliteta, rušenje javnog reda i mira te na maloljetničku delikvenciju i zapušteni odgoj djece i omladine (Dude, 1966: 557-562).

Da bi se vršila decentralizacija, trebalo je razmatrati administrativni i izvršni kapacitet općinskih organa i savjeta unutarnjih poslova. Pišući o sastanku Savjeta za unutarnje poslove u općini Centar-Sarajevo, Vlado Kecman je rekao da se postavlja pitanje "da li služba unutrašnjih poslova može realno rješavati sva pitanja iz domena javnog reda i mira sama?” Istovremeno je u Vojvodini Vladimir Lalić ukazao na nedostatke u suradnji općinskih organa unutarnjih poslova i općinskih savjeta u skupštinama općina. "Raspravljalo se o izvršavanju ili bolje rečeno neizvršavanju zaključaka... Skupština opštine, a pogotovo savet za unutrašnje poslove, nema na koga dalje da prenosi načelne stavove" (Lalić, 1966: 568).

Treba dakle na decentralizaciju unutarnjih poslova gledati kao na dugotrajni razvoj i kao na proces u kojem su ponekad načinjena dva koraka naprijed, a onda 
jedan korak unatrag. Tako piše i Ante Granić 1967. u članku o reorganizaciji službe javne sigurnosti: "U opštinama je delimično već ostvaren, a delimično je još u toku proces organizacionog objedinjavanja svih poslova..." (Granić, 1967: 568). Milicija mora biti "prvenstveno okrenuta i angažovana na zadacima koji su od neposrednog interesa za samu opštinu" kako bi sigurnosno stanje u općini bilo što optimalnije. Granić je ukazao na značajne varijacije strukturiranja organa unutarnjih poslova u pojedinim republikama (ibid.: 16). Općine su trebale igrati osnovnu ulogu u izvršavanju unutarnjih poslova, ali ponekad su, nažalost, djelovale kao zapreke. "Bržem integrisanju, a time i kvalitativnom poboljšanju Službe javne bezbednosti za teritorije više opština u regionima sa slabo razvijenom problematikom iz oblasti unutrašnjih poslova često stoje na putu nastojanja opštinskih skupština da po svaku cenu organizuju vršenje svih poslova javne bezbednosti u opštini, iako za to nema stvarne potrebe, a često ni mogućnosti” (ibid.: 18).

Poslije smjene Rankovića i Lukića savezni sekretar unutarnjih poslova postao je Radovan Stijačić, koji je ponovo istaknuo potrebu decentralizacije i "demokratizacije" organa unutarnjih poslova. Po Stijačiću, organi unutarnjih poslova su se tijekom prva dva desetljeća previše bavili "tako reći sam[i] sobom. ... Ovaj element u radu službe nije još prevaziđen u potpunosti” (Stijačić, 1967: 9). Premda se složio s time da su općinski organi unutarnjih poslova važni, Stijačić se očigledno bojao da bi stvari mogle otići u drugu krajnost i zato se izrazio kao protivnik "zatvorenosti" općina u svojim administrativnim granicama. "Bezbednost se na teritoriji određene opštine može uspješno održavati samo u sklopu šire društvene zajednice" (ibid.: 10). Važno je bilo i pitanje financija i (zlo)upotrebe milicije. "Valja istaći da je u velikom broju opština u kojima se finansira Milicija iz budžeta opštine došlo do degradacije Milicije na tzv. opštinsku stražu, redarsku i kurirsku službu. ... Takva je tendencija u suprotnosti sa odredbama Osnovnog zakona o unutrašnjim poslovima" (ibid.). Vladimir Lalić je kasnije inzistirao na zakonitosti i naglašavao da "pojedinačni akti opštinskih organa uprave moraju biti u skladu sa pozitivnim propisima", što očito nije bilo slučaj (Lalić, 1968: 37-40).

Stijačić je na kraju svog članka napisao da "predstoji realizacija drugog, rekao bih značajnijeg, dijela" restrukturiranja: "poboljšanje kvalifikacione strukture kadra, nacionalnog sastava, povećanje efikasnosti i bolje tehničke opremljenosti”. Nisu još bila riješena sva pitanja "reorganizacije organa unutrašnjih poslova u opštinama, ili su, pak, prva rješenja naišla na teškoće u fazi sprovođenja" (Stijačić, 1967: 15). ${ }^{11}$

Dalji razvoj decentralizacije pratili su novi zakoni o unutarnjim poslovima. Novi takav zakon SR Hrvatske komentirao je Vjekoslav Dude. "Time je Sabor... prvi put u svojoj zakonodavnoj djelatnosti donio normativni akt iz oblasti unutraš-

11 O nacionalnom sustavu organa unutarnjih poslova vidi i Trutin, 1970: 57-64. 
njih poslova na nivou zakona, jer je ranije ova oblast spadala u isključivo zakonodavstvo federacije" (Dude, 1968: 86). Po novom zakonu, potvrđeno je bilo da svaka općina ima organ javne sigurnosti. "To je jedna od značajnih novina utvrđenih ovim zakonom, jer je do sada na teritoriju SR bilo samo 27 organa (8 kotarskih, 14 međuopćinskih i 5 općinskih) koji su vršili poslove iz nadležnosti Službe državne sigurnosti, Službe za suzbijanje kriminaliteta i službe Milicije, iako u SR Hrvatskoj ima 104 općine" (ibid.). U istoj godini je povodom proslave Dana ustanka naroda Hrvatske - 27. srpnja - otvorena nova stanica milicije u Trnju u Zagrebu. Otvaranje te nove stanice kao i integracija službe Narodne milicije i kriminalističke službe bili su prikazani kao posljedice Četvrtog plenuma (Petrićević, 1968: 78-80).

Novi zakon je skupštini općine dao ovlaštenje da utvrđuje broj radnika milicije u općini, s tim što je skupština morala tražiti mišljenje republičkog sekretara. "Posebna novina u Republičkom zakonu su centri javne sigurnosti. ... Ti centri nisu drugostepena upravna instanca u odnosu na općinske organe, nego stručno-tehničke organizacione jedinice" (Dude, 1968: 88). Za razliku od organa javne sigurnosti, SDS je radio neposredno na republičkom nivou, a općinski organi nisu igrali nikakvu ulogu u toj sferi. I dalje se razmatralo pitanje financiranja organa unutarnjih poslova. Naime, ti su organi kao jedini upravni organi financirani isključivo iz republičkog proračuna. Ali neki su smatrali da "sredstva za redovnu djelatnost osigurava ona društveno-politička zajednica čije poslove organ vrši”" (ibid.: 92). To pitanje dobilo je dodatnu važnost s obzirom na činjenicu da je mnogo organa unutarnjih poslova u SR Hrvatskoj imalo zastarjelu opremu. Drugi problem je bio da su neke manje ili manje razvijene općine inzistirale na tome da sadrže kapacitete što se tiče javne sigurnosti za koje nisu imale sredstva. "Niz opština, iako nemaju potrebe a neke ni materijalnih mogućnosti da održavaju kompletnu Službu javne bezbednosti, nastoje da je zadrže" (“Mesto i uloga...”, 1968: 9).

Poželjan je bio cilj "afirmisanja opština kao nosilaca i odgovornih činilaca bezbednosti. Pri tom se nije gubilo iz vida da Služba javne bezbednosti mora zadržati svoje funkcionalno jedinstvo na području Republike stvaranjem centara, odnosno zajedničkih organa na principima društvenog dogovaranja u međuopštinske saradnje, za obavljanje specijalističkih poslova” (Puvalić, 1971: 8). Neke su se općine previše zatvarale u svoje granice, druge su pak pokazivale dobre inicijative što se tiče međuopćinske suradnje. Važno je i to što su ranije tri službe (kriminalistička, pogranična i milicija) bile objedinjene u jednu. Općinske skupštine nadzirale su rad službe javne sigurnosti, i to na način da je služba skupštini općine morala podnijeti godišnji izvještaj o svom radu.

Te 1968. godine došlo je i do novih sigurnosno-političkih izuma u Jugoslaviji: društvene samozaštite i općenarodne obrane. Riječ je ne samo o nastavljanju decentralizacije nego, naravno, i o reakciji prije svega na invaziju Čehoslovačke od Var- 
šavskog pakta (Dulić i Kostić, 2010). Bojan Škrk naglasio je pozitivan razvoj poslije Četvrtog plenuma i postavio nove sigurnosne koncepte u kontekst tog razvoja: "Sve do IV plenuma CK SKJ u praksi se polazilo od koncepcije da treba društvenu imovinu prvenstveno štititi jakim vanjskim aparatom, organizovanjem u brojnim i glomaznim inspekcijama i organima unutrašnjih poslova. Ta shvatanja su prevaziđena, ali kod pojedinih naših radnika još postoji određena dezorijentacija, jer se u svom radu još nisu u celini prilagodili i nisu našli svoje pravo mesto u našim samoupravnim društvenim odnosima" (Škrk, 1968: 4). Decentralizacija je dakle važna ne samo kao prenošenje sigurnosnih dužnosti i obaveza sa saveza na republike i autonomne pokrajine nego i kao "usklađivanje rada svih društvenih faktora" na boljoj sigurnosti društva i države. Tu je ideju razvijao i Lajčo Klajn: "Potpunije prenošenje poslova na opštinske organe unutrašnjih poslova omogućilo je da opštine $u$ znatno većoj meri nego ranije obezbede materijalna sredstva za delatnost organa i pomoć u rešavanju organizacionih i kadrovskih problema u ovoj službi” (1968: 9). Klajn je zagovarao daljnju reorganizaciju i osposobljavanje općinskih organa i poštovanje nacionalnih struktura. Ili, prema riječima Ivana Ginovskog, svaki građanin mora učestvovati u sigurnosti (Ginovski, 1969: 3-6).

Ginovski je dotaknuo i pitanje kontrole službe javne sigurnosti. Tu je bila vidljiva skeptičnost službenika unutarnjih poslova prema takvoj kontroli - treba, naravno, dodati da policija često nerado prihvaća takvu kontrolu i u demokratskim društvima. Konzervatizam Ginovskog i partijske države jasno se vidio kada je pisao o infiltraciji "kvaziliberalističkih ponašanja i drugih destruktivnih delovanja $u$ ovom društvu. Ova proizvoljna tumačenja često proizilaze i od sredina koje, maskirajući se plaštom samouprave i demokratije, zalažu se za svoje uske, privatne interese" (ibid.: 5). Poznata je činjenica da si Savez komunista, usprkos svim promjenama i reformama od Četvrtog plenuma nadalje, do kraja 1980-ih nikada nije dopustio da izgubi kontrolu nad državom, uključujući organe unutarnjih poslova.

Društvena samozaštita i općenarodna obrana su kao pojmovi sa sobom nosili diskusiju o ulozi građana u sigurnosnom sistemu te o samom ustroju tog sistema. Zanimljivo je da su u tom pogledu izvršena "obimna ispitivanja i anketiranja predstavnika opštinskih skupština, društveno-političkih i radnih organizacija i odgovornih državnih organa" ("Mesto i uloga...", 1968: 3). ${ }^{12}$ U tome je sudjelovalo više od 1.500 osoba. Osim organa unutarnjih poslova, važnu su ulogu igrale i općinske konferencije Socijalističkog saveza radnog naroda (SSRN) te općinski savjeti za društvenu sigurnost i narodnu obranu. Opet je bilo potrebno normativno prilagođavanje općina. Naime, “opštinske skupštine, radne organizacije i mesne zajednice još

12 Indikativna su i dva druga naslova iz tog broja: "Putem samoupravljanja suprotstavimo radnog čoveka svim pojavama neprijateljske delatnosti" i "Građani su jedinstveni kad je u pitanju bezbednost zemlje". 
uvek nisu svojim normativnim aktima regulisale svoja prava i obaveze iz oblasti društvene bezbednosti" (Čanković, 1968: 29).

U kontekstu društvene samozaštite i općenarodne obrane može se govoriti o militarizaciji društva. Pojmovi kao što su "široka mobilizacija svih društvenih snaga i građana i njihovo uključivanje" ukazali su na opsežnu suštinu željenog sigurnosnog sustava Jugoslavije (Mataković, 1971: 3). Zanimljivo je da je ideja o društvenoj samozaštiti najprije pokrenuta u SR Hrvatskoj (ibid.: 4). Ključno je bilo sudjelovanje svakoga građanina - uključujući i djecu - u "sigurnosnoj kulturi" zemlje. A "prevladalo je mišljenje da je naglasak na djelovanja društveno-političkih organizacija a ne stručnih službi (represija: sud, javno tužilaštvo, Služba javne sigurnosti)" (ibid.: 7). Došlo je do ogromnog broja savjetovanja na svim nivoima - od savezne države i republike do mjesnih zajednica - koja su ukazala "na postojanje niza neriješenih pitanja". Zanemaren je bio "jedan veoma značajan aspekt problema: odgojno-obrazovni i moralni” (ibid.: 8). S obzirom na to da je u tadašnjim školama postojala predvojnička obuka i poslije ONO i DSZ, nije baš jasno zašto je autor smatrao da je taj aspekt zanemaren.

Prema zakonu SR Hrvatske o unutarnjim poslovima, općine su mogle osnivati "specijalizirane radne organizacije koje osiguravaju imovinu radnih i drugih organizacija" (ibid.: 16). Takve su organizacije već djelovale u nekim gradovima u Hrvatskoj, obično pod nazivom "Sigurnost". Što se tiče sigurnosti zemlje, ne treba ni zaboraviti da je "milicija... kao najbrojniji i uniformisani deo organa unutrašnjih poslova, tretirana kao deo oružanih snaga SFRJ u sklopu teritorijalne odbrane... Imajući u vidu svoju ulogu u sistemu opštenarodne odbrane, organi unutrašnjih poslova su, posle donošenja Zakona o narodnoj odbrani, pristupili intenzivnim pripremama u cilju osposobljavanja za rad u uslovima neposredne ratne opasnosti ili rata" (Puvalić, 1971: 14). Tu, naravno, postoji i izrazito politička dimenzija u kontekstu zaštite obrane partijske države od opasnosti "kontrarevolucije" (Levkov, 1972: 4). Ta se opasnost, koja je u nekoliko navrata nestajala, vraćala u političku upotrebu prilikom kriznih događaja (npr. suzbijanja studentskih demonstracija 1968., Hrvatskog proljeća 1971. i kosovskih demonstracija 1981.).

Odnos građana i organa unutarnjih poslova trebao je biti interaktivan. Građanin je trebao na odgovoran i aktivan način sudjelovati u stvaranju bolje sigurnosne situacije u svojoj sredini, a milicioner je trebao biti "društveno-politički radnik" ("Milicioner...", 1970: 29-32). Milicioner je dakle imao dvostruku ulogu: bio je ne samo organ unutarnjih poslova nego i građanin-suučesnik u radu mjesnih zajednica, građanin koji svojim djelovanjem i ponašanjem daje dobar primjer sugrađanima. Savezni sekretar Radovan Stijačić je zajedno s general-potpukovnikom JNA Ivanom Miškovićem 1970. godine opet podsjetio na odgovornost svakoga građanina za sigurnost zemlje, lokalnih sredina, organizacija i zajednica (Stijačić i Mišković, 1970: 3-9). Stijačić je nešto kasnije napisao da "poslovi bezbednosti poslednjih go- 
dina sve više postaju predmet razmatranja širih društvenih i samoupravnih institucija, čime su u značajnoj meri prevaziđena shvatanja da su ovi poslovi prvenstveno stvar specijalizovanih službi" ("Izjava saveznog...”, 1970: 3-9).

U međuvremenu je u Skupštini SR Srbije sigurnosni koncept bio potvrđen tako što je stavljen naglasak na potrebu međuopćinske suradnje. "Neophodno je obezbediti da službe unutrašnjih poslova ostvaruju međusobnu saradnju i deluju jedinstveno u izvršavanju zadataka na teritoriji Republike i da za svoj rad odgovaraju skupštinama društveno-političkih zajednica. Potrebno je nastaviti i podržati integracione procese u oblasti unutrašnjih poslova" ("Zaključci...", 1970: 23). Te formulacije vrijedile su i za organe unutarnjih poslova u drugim republikama. To se vidi po tome što je gotovo istodobno Mato Krpan, republički sekretar za unutarnje poslove u SR Hrvatskoj, pisao o značaju samozaštite. Spomenuo je ustavne promjene u Hrvatskoj te dodao da svaka općina u Hrvatskoj sada ima stanicu javne sigurnosti. "Drugi princip decentralizacije, sastoji se u tome da smo spustili tu službu bliže narodu, da je općinska skupština znatno više zainteresirana za ta pitanja i da je ovlaštena u nizu pitanja. Ne samo općinska skupština, već i ostali društveno-politički faktori se bave tim problemima" (Krpan, 1970: 4). Dodao je i to da je "povjerenje prema ljudima osnovna misao kojom se služba u svojim pristupima mora da služi” (ibid.).

Lijepe i idealistične riječi bilo je lako napisati, ali njihovo izvršenje bilo je nešto sasvim drugo, a niz članaka ukazuje na teškoće u izvršavanju. Često je dolazilo do nesporazuma ili nesigurnosti što se tiče suradnje općina i organa unutarnjih poslova. Neke su se općine očigledno previše ili predetaljno - u smislu engleskog pojma micromanagement - bavile službom javne sigurnosti, dok su druge obraćale premalo pažnje na nju. S obzirom na to da je došlo i do proširenja sigurnosnog koncepta dodatkom društvene samozaštite i općenarodne obrane, sigurnosni poslovi trpjeli su i zbog sudjelovanja previše aktera. To se jasno vidi u jednoj rečenici u članku o razvijanju sistema društvene samozaštite, gdje piše da "opštinske skupštine u saradnji sa Socijalističkim savezom radnog naroda, Savezom komunista, Savezom socijalističke omladine, Savezom sindikata, Savezom udruženja boraca narodnooslobodilačkog rata, Savezom rezervnih vojnih starešina i organima samoupravljanja treba kontinuirano da rade na jačanju odgovornosti i daljoj izgradnji sistema društvene samozaštite" ("Mere za dalje...", 1970: 4). Ako se uzme u obzir da isti članak malo kasnije spominje i ulogu mjesnih zajednica, više je nego vidljivo da je koordinacija tih poslova predstavljala ogroman izazov.

\section{Rast kriminaliteta u SR Hrvatskoj}

Važan kontekstualni element diskusija o razvoju organa unutarnjih poslova i službe javne sigurnosti čini rast kriminaliteta u SR Hrvatskoj. Modernizacija i urbanizacija Jugoslavije koje su bile popraćene većom mobilnošću i masovnom migracijom 
stvorile su, uz još nekoliko faktora, uvjete za povećanje broja kaznenih djela, a time i problem kojim se bavio Josip Mataković u časopisu 13. maj. Prvi članak koji je bacio svjetlo na specifičnost tog problema u Hrvatskoj najprije je obradio kriminalitet na turističkim područjima SR Hrvatske. Brojke su bile zabrinjavajuće: "U periodu od 1962-1968. g. kod organa unutrašnjih poslova na turističkom području zabilježen je porast imovinskih delikata za 479\% (od 1.998 u 1962. godini na 13.563 u 1968. godini), dok je istovremeno porast ovih delikata u SRH iznosio 54,2\% (od 25.273 na 39.656 krivičnih djela)" (Mataković, 1970b: 9).

Mataković se 1970. bavio općim porastom kriminaliteta u SR Hrvatskoj, dokumentirajući daljnju tendenciju rasta kriminaliteta. Uzimajući 1962. kao početnu godinu, pokazao je da je broj kaznenih djela porastao čak za 87\% (Mataković, 1970a: 30). Uz "obična" kaznena djela kao što su ona protiv društvene i privatne imovine, opće sigurnosti ljudi i imovine, života i tijela itd., Mataković je ukazao i na porast kaznenih djela društveno-ekonomskog kriminaliteta. Što se tiče te vrste kriminaliteta, situacija je postala složenija zbog visokog stupnja organiziranosti kriminalaca, tehničke opremljenosti te internacionalizacije takvih djela. I droge su postajale sve problematičnije (ibid.: 32). Kriminalitet u turističkoj sezoni i dalje je bio velik izazov, a i porast kaznenih djela maloljetnika bio je zabrinjavajući. Na svu sreću, "usporedo sa tendencijom rasta ukupne mase kriminaliteta u porastu je broj krivičnih djela sa nepoznatim učiniocem ali ujedno - i broj naknadno otkrivenih učinilaca" (ibid.: 40).

Na kraju svog članka Mataković se kratko posvetio i pitanju angažiranja "vanresorskih faktora na provođenju samozaštite". Primijetio je da je Služba javne sigurnosti sudjelovala u savjetovanjima po tom pitanju i ocijenio to sudjelovanje kao produktivno i s pozitivnim rezultatima. "Iako sporo, ipak se sve češće i obimnije ostvaruju prijedlozi Službe javne sigurnosti podneseni radnim i drugim organizacijama da poduzmu određene preventivne mjere... Na tom planu Služba javne sigurnosti kao stručna služba poduzima daljnje akcije - od obilaska radnih organizacija radi upozoravanja na propuste $u$ tehničkom i fizičkom osiguranju, do izvještavanja općinskih skupština i drugih organa, organiziranja savjetovanja sa drugim organima i stručnim službama i dr." (ibid.: 47).

\section{Zaključak i daljnji razvoj istraživanja}

Rečeno je na početku ovog članka da je izbor časopisa 13. maj kao glavnog izvora za ovaj rad simptomatičan za problematično stanje arhivske građe o službi javne sigurnosti u SR Hrvatskoj. Ali kao povjesničar koji se već godinama bavi pitanjima sigurnosti i unutarnjih poslova, smatram da je važno prihvatiti izazov i nastaviti istraživanje. Predmet funkcioniranja službe javne sigurnosti prevažan je za bolje razumijevanje povijesti socijalističke Hrvatske i Jugoslavije da bismo ga smjeli 
ignorirati. Bilo bi posebno zanimljivo detaljnije razmatrati rad kotarskih i općinskih savjeta za unutarnje poslove.

Ne može se isključiti mogućnost da je značajna količina relevantne arhivske građe i dalje u posjedu Ministarstva unutarnjih poslova Republike Hrvatske, koje još uvijek ima vrlo problematičan odnos prema svojim dužnostima u vezi s primopredajom arhivske građe Hrvatskom državnom arhivu. U međuvremenu moguće je arhivsko istraživanje $u$ fondovima općinskih skupština i SSRN-a te organa Saveza komunista Hrvatske, fondovima u kojima povjesničar nailazi na korisnu građu koja spominje relevantna pitanja i debate o razvoju unutarnjih poslova. Ali isto tako bit će potrebno proširiti fokus daljnjeg istraživanja na šira sigurnosna pitanja. Konkretno to znači djelomično prebacivanje fokusa daljnjeg istraživanja na društvenu samozaštitu i općenarodnu obranu.

U međuvremenu članci iz časopisa 13. maj ukazuju na teme koje su bile značajne za sve građane SR Hrvatske i Jugoslavije. Naravno, treba uzeti u obzir da su autori tih članaka radili za organe unutarnjih poslova i da se njihove misli moraju razmatrati u tom kontekstu. Tu nećemo nailaziti na temeljite kritike partijske države i njezinih najvećih neuspjeha i problema. Ali svakako nailazimo na konstruktivnu kritiku koja nam pruža točniju sliku funkcioniranja tih organa, odnosno promjena u službi javne sigurnosti, tema o kojima i dalje jako malo znamo. Cijenim da pažljivo čitanje takvih članaka, uz neophodno daljnje istraživanje, omogućuje bolje i manje ideološki pristrano razumijevanje povijesti te bivše države i društva.

\section{LITERATURA}

Cvetković, Srđan. 2011. Između srpa i čekića 2: Politička represija u Srbiji, 1953-1985. Službeni glasnik. Beograd.

Cvetković, Srđan. 2013. Između srpa i čekića 3: Oblici otpora komunističkom režimu u Srbiji, 1944-1991. Službeni glasnik. Beograd.

Dornik Šubelj, Ljuba. 1999. Oddelek za zaščito naroda za Slovenijo. ARS. Ljubljana.

Dornik Šubelj, Ljuba. 2013. Ozna in prevzem oblasti 1944-46. Modrijan. Ljubljana.

Dulić, Tomislav i Roland Kostić. 2010. "Yugoslavs in Arms: Guerrilla Tradition, Total Defence and the Ethnic Security Dilemma". Europe-Asia Studies, (62), 7: 10511072.

Fitzpatrick, Sheila (ur.). 2000. Stalinism: New Directions. Routledge. London.

Hagenloh, Paul. 2009. Stalin's Police: Public Order and Mass Repression in the USSR, 1926-1941. Woodrow Wilson Center Press. Washington, DC.

Koprić, Ivan. 1987. "Razvitak formiranja društveno-političkih zajednica u SFRJ". Pravnik, 20: 19-32. 
Kotkin, Stephen. 1995. Magnetic Mountain: Stalinism as a Civilization. University of California Press. Berkeley.

Nikolić, Kosta. 2013. Mač revolucije, Ozna u Jugoslaviji. Službeni glasnik. Beograd.

Perković, Josip i Jan Gabriš. 1997. "Služba državne sigurnosti republičkog sekretarijata za unutarnje poslove SR Hrvatske u vremenu 1980.-30. svibnja 1990. godine”.

Previšić, Martin. 2019. Povijest Golog otoka. Fraktura. Zagreb.

Radelić, Zdenko. 2019. Obavještajni centri, Ozna i Udba u Hrvatskoj (1942.-1954.); Obavještajni centri, Ozna i Udba u Hrvatskoj: Kadrovi (1942.-1954.). Hrvatski institut za povijest. Zagreb.

Rusinow, Dennison. 1978. The Yugoslav Experiment, 1948-1974. University of California Press. Berkeley.

Rusinow, Dennison. 2008. Yugoslavia: Oblique Insights and Observations. University of Pittsburgh Press. Pittsburgh.

Shearer, David R. 2009. Policing Stalin's Socialism: Repression and Social Order in the Soviet Union, 1924-1953. Yale University Press. New Haven.

Siegelbaum, Lewis i Andrei Sokolov. 2000. Stalinism as a Way of Life: A Narrative in Documents. Yale University Press. New Haven.

\section{Izvori}

Čanković, Dane. 1968. "Putem samoupravljanja suprotstavimo radnog čoveka svim pojavama neprijateljske delatnosti”. 13. maj, (21), 4 (travanj).

Dude, Vjekoslav. 1966. "Osvrt na rad savjeta za unutrašnje poslove Skupštine općine centar - Zagreb". 13. maj, (19), 6 (lipanj).

Dude, Vjekoslav. 1968. "Povodom donošenja zakona u unutrašnjim poslovima SR Hrvatske”. 13. maj, (21), 1 (siječanj).

Ginovski, Ivan. 1969. "Ostvarena je organizaciona struktura koja je pokazala stabilnost i uspeh u rešavanju krupnih zadataka organa unutrašnjih poslova”. 13. maj, (22), 1 (siječanj).

Granić, Ante. 1967. "Rad na organizovanju službe javne bezbednosti”. 13. maj, (20), 11 (studeni).

"Izjava saveznog sekretara za unutrašnje poslove Radovana Stijačića povodom 13. maja". 1970. 13. maj, (23), 5 (svibanj).

Klajn, Lajčo. 1968. "Skupština AP Vojvodine o funkcionisanju službe unutrašnjih poslova na teritoriji pokrajine u novim uslovima". 13. maj, (21), 7-8 (srpanj-kolovoz).

Krpan, Mato. 1970. "Samozaštita je misao bliska našim ljudima". 13. maj, (23), 6 (lipanj).

Krzić, Enver. 1965. "Poslije usklađivanja saveznih propisa sa ustavom”. 13. maj, (18), 12 (prosinac). 
Lalić, Vladimir. 1966. "Opštinska skupština i savet za unutrašnje poslove moraju se baviti konkretnim pitanjima kriminaliteta". 13. maj, (19), 6 (lipanj).

Lalić, Vladimir. 1968. "Pojedinačni akti opštinskih organa uprave moraju biti u skladu sa pozitivnim organima”. 13. maj, (21), 7-8 (srpanj-kolovoz).

Levkov, Milivoje. 1972. "Bezbednost značajna komponenta koncepcije opštenarodne odbrane u svetlu savremene obaveštajno-subverzivne aktivnosti u našem prostoru". 13. maj, (25), 2 (veljača).

Lukić, Vojin. 1965. "Neki zadaci službenika organa unutrašnjih poslova u svetlu odluka VIII kongresa". 13. maj, (18), 4 (travanj).

Mataković, Josip. 1970a. "Kretanje kriminaliteta na području SR Hrvatske u 1970. godini". 13. maj, (23), 6 (lipanj).

Mataković, Josip. 1970b. "Problemi Službe javne sigurnosti na turističkom području". 13. maj, (23), 5 (svibanj).

Mataković, Josip. 1971. "Mjere i akcije na provođenju društvene samozaštite u SR Hrvatskoj". 13. maj, (24), 10 (listopad).

"Mere za dalje razvijanje sistema društvene samozaštite". 1970. 13. maj, (23), 11 (studeni).

"Mesto i uloga građana, organizacija i organa u sistemu društvene bezbednosti”. 1968. 13. maj, (21), 4 (travanj).

"Milicioner - društveno-politički radnik". 1970. 13. maj, (23), 2 (veljača).

Mišković, Milan. 1959. "O petnaesto-godišnjici resora unutrašnjih poslova”. Priručnik, (7), 2: 117-128.

Oreč, Mate. 1971. "Otvorenost Jugoslavije i razmena informacija sa svetom”. 13. maj, (24), 3 (ožujak).

Pasinović, Krsto. 1959. "Neki elementi društvenog upravljanja u organima unutrašnjih poslova". Priručnik, (7), 2.

Petrićević, Josip. 1968. "Nova stanica milicije u Zagrebu”. 13. maj, (21), 7-8 (srpanjkolovoz).

Puvalić, Stevo. 1971. "Organizacija i funkcionisanje Službe javne bezbednosti”. 13. maj, (24), 11 (studeni).

Stijačić, Radovan. 1967. “Služba unutrašnjih poslova može biti efikasna samo u tijesnoj saradnji i povezanosti sa društvom i njegovim demokratskim institucijama". 13. maj, (20), 12 (prosinac).

Stijačić, Radovan i Ivan Mišković. 1970. "Bezbednost i odbrana zemlje su stvar svih građana, radnih i društveno-političkih organizacija i zajednica". 13. maj, (23), 4 (travanj).

Škrk, Bojan. 1968. "Organizovanje i unapređenje društvene samozaštite”. 13. maj, (21), 11 (studeni). 
Trutin, Ivan. 1970. "Kadrovi kao faktor efikasnosti organa unutrašnjih poslova". 13. maj, (23), 9 (rujan).

Uredništvo. 1953. “Uz prvi broj”. Priručnik za stručno obrazovanje službenika unutrašnjih poslova, (1), 1 (studeni-prosinac).

"Zaključci republičkog i organizaciono-političkog veća Skupštine SR Srbije o funkcionisanju službe unutrašnjih poslova". 1970. 13. maj, (23), 4 (travanj).

Žarković, Miroslav. 1965. "Neki aktuelni problemi saveta za unutrašnje poslove”. 13. maj, (18), 3 (ožujak).

\title{
Christian Axboe Nielsen \\ DECENTRALIZATION OF THE ORGANS OF INTERNAL AFFAIRS IN THE SOCIALIST REPUBLIC OF CROATIA
}

\begin{abstract}
Summary
How did the organs of internal affairs in the Socialist Republic of Croatia and in socialist Yugoslavia develop, what did they actually do, what changes occurred with respect to them, and why? During approximately the first two decades of socialist Yugoslavia, issues related to police and state security - or, as they were officially called, the organs of internal affairs - were, like most other matters in the country, heavily centralized. However, there are indications that 1966 may not have been as significant a watershed moment as is commonly thought, and that some important changes were accelerated rather than triggered after the ouster of Ranković. This article is primarily based on sources from 13. maj, the official journal of the Federal Secretariat for Internal Affairs (SSUP). A careful reading of this journal reveals very detailed articles dealing with legal, conceptual, technical and practical issues affecting policing. The journal is therefore a good place to gather information for a better understanding of policing and internal affairs in Yugoslavia. This article examines and analyses the beginning of decentralization of internal affairs in Croatia, above all with regard to public security bodies.
\end{abstract}

Keywords: Ministry of Internal Affairs, Decentralization, Municipalities, Police, Public Security

Christian Axboe Nielsen je izvanredni profesor povijesti i sigurnosnih studija na Sveučilištu Aarhus u Danskoj.

Kontakt: Christian Axboe Nielsen, School of Culture and Society, Jens Chr. Skous Vej 5, 8000 Aarhus C, Danska. E-mail: christian.a.nielsen@cas.au.dk 